\title{
Biochemical and Microbiological Quality of Cultured Shrimp Litopenaeus vannamei of Different Farms of Ratnagiri
}

\author{
P.S. Tawade ${ }^{1 *}$, J.M. Koli ${ }^{2}$, S.B. Patange ${ }^{3}$, S.T. Sharangdher ${ }^{3}$ and A.S. Mohite ${ }^{3}$ \\ ${ }^{1}$ Post Graduate Student, Fish Processing Technology and Microbiology (FPTM), College of \\ Fisheries, Shirgaon, Ratnagiri, India \\ ${ }^{2}$ Major Advisor (SAC, Chairman), College of Fisheries, Shirgaon, Ratnagiri, India \\ ${ }^{3}$ Advisor Members, College of Fisheries, Shirgaon, Ratnagiri, India
}

*Corresponding author:

\section{Keywords}

Shrimp

(Litopenaeus

vannamei), Sensory

evaluation,

Physicochemical

and Microbiological

quality

Article Info

Accepted:

17 May 2019

Available Online:

10 June 2019

\section{A B S T R A C T}

Shrimp aquaculture has become an economically important one and production has decreased in recent years due to the spread of infectious diseases, mostly that caused by bacterial infection. The shrimp are affected by the toxic substances which eventually enter in to their systems and bring about external damages. This study explores, it was aimed to assessment of the physiochemical and microbiological quality of different farmed shrimp from Ratnagiri. The results of this attempt for the study such as sensory, physicochemical, proximate composition and microbiological quality of shrimp Litopenaeus vannamei cultured in three different farms of Ratnagiri were compared. Fresh shrimps were analyzed for sensory attributes where, natural and bright colour, excellent odour, elastic and rigid texture with very good appearance was observed. The highest protein content (17.6\%) was observed in samples collected from Varavde farm and lowest (16.8\%) was observed in the samples collected from Ranpar farm. The highest fat content was found in the samples collected from Nevre farm i.e. $1.5 \%$ and lowest was found in the samples collected from Ranpar farm i.e. 1.3\%. The highest moisture content was recorded in the samples of Ranpar farm i.e. $77.9 \%$ and lowest was recorded in the samples of Varavde farm i.e. 73.2\%. The highest and lowest ash content was observed in the sample collected from Ranpar farm i.e. $1.9 \%$ and $1.4 \%$ respectively. The carbohydrate content was higher in the samples (2.4\%) collected from Varavde farm and lowest in the samples of Nevre farm (1.5\%). The TMA level in the sample collected from Ranpar, Nevre and Varavde farm was ranged between 2.2 to $2.4 \mathrm{mg} / 100 \mathrm{~g}, 2.4$ to $3.0 \mathrm{mg} / 100 \mathrm{~g}$ and 3.2 to $3.3 \mathrm{mg} / 100 \mathrm{~g}$ respectively. TVB-N levels of fresh shrimp sample collected from Ranpar and Varavde farm ranged between 11.1 to $13.6 \mathrm{mg} / 100 \mathrm{~g}, 13.0$ to $13.1 \mathrm{mg} / 100 \mathrm{~g}$ respectively. The value estimated from the sample collected from Nevare farm was $13.0 \mathrm{mg} / 100 \mathrm{~g}$. Peroxide value of fresh shrimp sample collected from Ranpar, Nevare and Varavde farm ranged between 3.7 to 4.3 meq of $\mathrm{O}_{2} / \mathrm{Kg}, 3.3$ to 4.7 meq of $\mathrm{O}_{2} / \mathrm{Kg}$ and 2.3 to $3.3 \mathrm{meq}$ of $\mathrm{O}_{2} / \mathrm{Kg}$ respectively. Total bacterial count of samples collected from Ranpar, Nevare and Varavde showed an increasing trend during study period. Highest bacterial count was detected in the sample collected from Ranpar farm i.e. $1.03 \times 10^{6}$. An increase in the Staphylococcus count was observed throughout the study period at Ranpar and Varavde site; whereas a slight decrease was observed during second sampling at Nevare site. Salmonella, E. coli and L. monocytogenes was not detected in any sample throughout the study. So the present study revealed that the hygienic condition of the investigated shrimp farm was good on the basis of microbiological analysis. 


\section{Introduction}

Aquaculture is a profitable business with better scope for job opportunity and foreign exchange for the nation. Increased population and demand for seafood exerted huge fishing pressure on the natural fishery resources; thus led to decline in the capture fishery at an alarming rate. Aquaculture is an alternative solution at this crunch; hence this sector boomed globally including India (Joseph et al., 2017). Global commercialization and business involving fish and fish products largely depend on shrimp (Bhaskar et al., 1995).

White leg shrimp (L. vannamei) is one of the world's most popular shellfish and is mainly consumed in the North, Latin America, Europe and Asian countries (Puga-lopez, 2013). The L. vannamei production in India during the year 2017-18 was 6, 22,327 MT, which was $1,21,020 \mathrm{MT}$ more than the previous year production of 5, 01,297 MT, thus registering an increase of about $24 \%$. The share of L. vannamei in total shrimp production has been on the increase during $2017-18$ it reached $89.96 \%$ of the total shrimp aquaculture production in the country (MPEDA, 2018).

Crustaceans, such as shrimps, are an important source of protein worldwide (Heu et.al. 2003). Along with this it contains calcium, various extractable compounds and minerals for human body, while low in calorie and fat (Oksuz et al., 2009). Lipid of shrimp contains mostly polyunsaturated fatty acids (essential fatty acids). This essential fatty acid available in shrimp provides health benefits for human such as, eye (retina) and brain development and function (Connor et al., 1992). There are many inorganic elements in the body of shrimp that support associated vital physiological functions. Although shrimps are capable of extracting some of the elements from water, they do respond to dietary sources (Davis et al., 1992). Since these micronutrients are essential, their absence in the diet may lead to deficiency diseases. Some elements, such as copper, zinc, manganese, iron and chromium have useful biological function and are found in shrimp at acceptable levels are very useful for human health (Oksuz et al., 2009).

Studies on the shelf life and quality of sea foods have entailed quantification of the microorganisms, trimethylamine (TMA) and total volatile basic (TVB) nitrogen (Huidobro et al., 2002). At the time of harvesting, ice is used as the method of preservation. A number of microbiological studies have shown so far the association of an array of pathogenic microorganisms with shrimp, resulting in food borne diseases like diarrhea, Salmonellosis, shigellosis, cholera and even some neurological diseases (Karunasagar et al., 2005). Microbiological contamination of shrimp may be due to poor hygienic condition including inappropriate processing, preservation and storage condition (Dalsgaard et al., 1995). Microbial growth and activity determine shelf-life and safety of various fresh and lightly preserved seafoods.

Therefore, identification of the spoilage associations facilitates the development of methods to determine, predict and extend shelf-life of these products (Dalsgaard, 2000). White leg shrimp, Penaeus vannamei aquaculture is a very important commercial activity in several parts of India. Penaeus vannamei, commercially known as "White leg shrimp or King prawn", has good demand in export and domestic market (MPEDA, 2018).

It is common practice to store shrimp in ice (at $0{ }^{\circ} \mathrm{C}$ ) to extend shelf-life. With the increase in the volume of production arises the need to improve on-site handling of shrimp. 
Shrimps deteriorate due to improper handling, and further processing can never bring back its freshness. Low quality frozen foods are related with improper processing and poor hygienic conditions. Contamination in shrimp may be due to poor hygienic condition including inappropriate processing, preservation and storage condition (Dalsgaard et al., 1995). Consequently, shrimps may be contaminated with different types of bacteria such as Vibrio spp., Salmonella spp., coliform, faecal coliform, streptococci and Staphylococcus spp., those spoil fishes and are responsible for causing cholera and other food borne disease outbreaks (Wallace et al., 1999).

Nowadays, shrimp plays a dominant role in the economy of India. Therefore, by considering the consumer health safety and economical sustain it is worth to maintain the microbiological quality of the shrimp. Along these lines, the present investigation will be attempted to evaluate physico-chemical properties of shrimp and to assess the microbiological quality of cultured shrimp from different farms located nearby Ratnagiri.

\section{Materials and Methods}

\section{Sample collection}

Fresh pacific white shrimp (L. vannamei) were collected from three different farms of Ratnagiri i.e. Nevre, Varavade and Ranpar once the average body weight of the respective farm reaches to $10 \mathrm{~g}$. The samples were analysed for sensory, proximate, biochemical and microbiological characteristics. Altogether 27 samples were analysed for different parameters mentioned. For each of the proximate, biochemical and microbial parameter the average values of three retailers were taken, analysed for mean and standard deviation and are reported in results.

\section{Sensory evaluation}

Sensory analysis of the shrimp sample was determined by standard method (Puga Lopez et al., 2005). The sensory attributes studied were appearance, odour, colour and texture. Initial sensory and quality evaluations were conducted to develop descriptors. Each panellist received cultured shrimp from Nevre, Varavade and Ranpar farm samples and they were asked to describe the appearance odour, colour, and texture state similarities and differences among the different cultured shrimp samples. Overall acceptability was evaluated during sensory evaluation by a group of ten trained panellists using a ten point Hedonic scale. During a sensory session, each panellist analyzed all shrimp at room temperature.

\section{Proximate composition}

Proximate composition such as Protein, Fat, Carbohydrates, Ash and Moisture content of the shrimp sample was determined by standard hot air oven method (AOAC, 2005).

\section{Biochemical analysis}

The TMA-N and TVB-N content of shrimp sample were determined by micro diffusion method of Conway (Beatty and Gibbons, 1936).

\section{Peroxide value}

Peroxide value of samples was determined method suggested by American Oil Chemistry Society (AOCS Method, 2011)

\section{Microbiological analysis}

Total plate count, Staphylococcus aureus, E. coli, Salmonella, Listeria monocytogenes Pseudomonas was determined according to method suggested by APHA (1992) 


\section{Statistical Analysis}

Sampling data were analyzed to the test significant difference in different sites by applying analysis of variance (ANOVA) tool available in MS-EXCEL 2010. The significant differences were tested by $5 \%$ level of significance and are mentioned as $\mathrm{p}<0.05$ for significant difference (Zar, 2014).

\section{Results and Discussion}

Recently, white leg shrimp become target species of shrimp culture among shrimp farmers in India to replace tiger shrimp (Penaeus monodon) culture. However, the baseline information on physico-chemical and microbiological analysis of farmed white leg shrimp culture is not well established. Therefore, this study was conducted and same discussed herewith.

\section{Proximate compositions}

\section{Protein}

The protein was found as the major constituent, indicating that shrimp muscle can be a good source of amino acids. The proximate composition of shrimp collected from each farm i.e. Nevre, Varavade and Ranpar were analysed. The highest protein content was recorded in the samples collected from Nevre farm i.e. $17.6 \%$ and lowest was observed in the samples collected from Ranpar farm i.e. $16.8 \%$ (Table 1). No significant difference $(\mathrm{p}>0.05)$ was observed between the farms under study. Similarly, Puga-lopez et al., (2013) worked on proximate composition of wild and farm harvested Pacific white leg shrimp. The protein content was in the range of $19.93 \pm 0.69$ to $20.10 \pm 0.52$. Gunalan et al., (2013) worked on nutritive value of cultured L. vannamei. The shrimp samples were collected from Surya Marine shrimp farm in
Bhimavaram, West Godavari district, Andhra Pradesh. The protein content found in the sample was $35.69 \%$. Ali et al., (2017) was assessed proximate composition of shrimp collected from fish landing center of Kasimedu Chennai, India. The crude protein of L. vannamei was estimated to be $17.9 \pm 0.05 \%$. This result of protein composition was similar in present study. While, Rostini and Pratama (2018) estimated the proximate composition of White shrimp (L. vannamei) collected from Indramayu waters. The protein content was $19.25 \pm 0.32$. Sriket et al., (2007) studied the proximate composition of shrimp samples collected from the farms in Songkhla and Suratthani provinces. The protein content of Penaeus vannamei was recorded to be $18.8 \pm 0.23 \%$ these values of protein is higher than the present investigation.

\section{Fat}

The maximum fat content was recorded in the samples of Nevre farm i.e. $1.4 \%$ and minimum observed in the sample collected from Varavade farm i.e. 1.3\% (Table 1). No significant difference $(p>0.05)$ was observed between the samples in present study. Rostini and Pratama (2018) recorded the proximate composition of white shrimp (L. vannamei) collected from Indramayu waters. The fat content in the sample was $0.30 \pm 0.01 \%$. Ali et al., (2017) worked on the fat content of the sample collected from fish landing center of Kasimedu Chennai, India. The crude lipid content of $L$. vannamei was estimated to be 0.94 \pm 0.04 . Gunalan et al., (2013) worked on the nutritive value of cultured L. vannamei. The shrimp samples were collected from Surya Marine shrimp farm in Bhimavaram, West Godavari district, Andhra Pradesh. The fat content was found in the sample was $19 \%$. Puga-lópez et al., (2013) estimated fat content of wild and farm harvested Pacific white shrimp (L. vannamei). The fat content was 
found in the range between $1.27 \pm 0.36$ to $1.34 \pm 0.18$. Sriket et al., (2007) studied the proximate composition of shrimp samples was collected from the farms in Songkhla and Suratthani provinces. The fat content was estimated to be $1.3 \pm 0.09$.

In the present investigation the fat content was observed in the range of $1.3 \pm 0.04$ to $1.5 \pm 0.44$ which was in conformation with studies of Puga-lopez et al., (2013) and Sriket et al., (2007). The present value of fat content was higher than that obtained by Rostini and Pratama (2018) and Ali et al., (2017). In the study conducted by Gunalan et al., (2013) very high lipid content (19\%) was observed; whereas lipid content in the present study was observed to be less than that of earlier reported. Lipid acts as major food reserves and the amount present in body may fluctuate according to temperature (Pillay and Nair, 1973), shrimp size, season, and environment, type of food available and stage of life cycle.

\section{Moisture}

The moisture content was observed in the range of $73.2 \%$ (Varavade farm) to $77.9 \%$ (Ranpar farm) (Table 1). There is no significant difference $(p>0.05)$ was observed between the samples collected. The moisture content of $L$. vannamei from Indramayu waters was reported to be $77.59 \pm 0.12$ by Rostini and Pratama (2018). Ali et al., (2017) recorded that the proximate composition of shrimp collected fish landing center of Kasimedu Chennai, India. The moisture was recorded to be $75.52 \pm 0.40$. Gunalan et al., (2013) studied nutritive value of cultured $L$. vannamei. The shrimp samples were collected from Surya Marine shrimp farm in Bhimavaram, West Godavari district, Andhra Pradesh. The moisture content was recorded to be $76.2 \%$. Puga-lopez et al., (2013) studied proximate composition of wild and farm harvested Pacific white shrimp. Shrimps had suitable moisture contents (73.14 to $73.91 \%$ ). Sriket et al., (2007) estimated the moisture content of $L$. vannamei from the farms in Songkhla and Suratthani provinces. The value was obtained to be $77.21 \pm 0.18$

The moisture content in the present study is in the range of $73.2 \pm 0.51$ to $77.9 \pm 2.72$ (Table 1). The earlier studies reported moisture content in the range of 73.14 Puga-lopez et al., (2013) to $77.59 \pm 0.12$ Rostini and Pratama (2018).

\section{Ash}

The highest and lowest ash content was observed in the samples collected from Ranpar farm i.e. $1.9 \%$ and $1.4 \%$ respectively (Table 1). No significant difference $(\mathrm{p}>0.05)$ was observed between farms under study. Puga-lopez et al., (2013) worked on proximate composition of wild and farm harvested Pacific white shrimp. The ash content was $2.10 \pm 1.05$ to $2.27 \pm 0.45$. Gunalan et al., (2013) worked on nutritive value of cultured L. vannamei. The shrimp samples were collected from Surya Marine shrimp farm in Bhimavaram, West Godavari district, Andhra Pradesh. The ash content found in the sample was $1.2 \%$. Rostini and Pratama (2018) estimated the proximate composition of White shrimp (L. vannamei) collected from Indramayu waters. The ash content observed in the sample was $1.38 \pm 0.11$. Ali et al., (2017) assessed proximate composition of shrimp collected from fish landing center of Kasimedu Chennai, India. The ash content estimated in the sample was 3.05 \pm 0.42 . Sriket et al., (2007) studied the proximate composition of shrimp samples collected from the farms in Songkhla and Suratthani provinces. The ash content was recorded to be $1.47 \pm 0.10$.

The ash content in the present study was observed in the range of $1.4 \pm 0.33$ to $1.9 \pm 0.25$ (Table 1) which was less than the earlier 
studies of Puga-lopez et al., (2013) and Ali et al., (2017). The value of ash content was in accordance with the results of Gunalan et al., (2013), Rostini and Pratama (2018) and Sriket et al., (2007). The ash content of any sample is a measure of the likely mineral content of such a sample.

High ash content in shrimps is due to the high level of chitin strengthened by a high level of calcium metal in the exoskeleton. Chitin is a linear polymer of acetyl D glucosamine that has properties similar to cellulose in many respects MacDonald et al., (1998).

\section{Carbohydrate}

The maximum carbohydrate was recorded in the samples collected from Varavade farm i.e. $2.4 \%$ and lowest was recorded from Nevre farm i.e. $1.5 \%$ (Table 1). Significant difference $(p<0.05)$ was observed between farms in the present study. The results are shown in table 1, 2 and 3.

Gunalan et al., (2013) worked on the proximate composition of cultured $L$. vannamei. The shrimp samples were collected from Surya Marine shrimp farm in Bhimavaram, West Godavari district, Andhra Pradesh. The carbohydrate content in the sample was recorded to be $3.20 \%$.

Ali et al., (2017) studied the proximate composition of shrimp collected from fish landing center of Kasimedu Chennai, India. The crude fibre of $L$. vannamei was estimated to be $1.33 \pm 0.03$. The carbohydrate content range $(1.5 \pm 0.05$ to $2.4 \pm 0.10)$ was observed to be slightly less than that reported by Gunalan et al., (2013) whereas it was higher than that reported by Ali et al., (2017). Proximate compositions in shrimp muscle are affected by several factors such as species, growth stage, feed and season (Karakoltsidis et al., 1995).

\section{Organoleptic evaluation}

In present study the sensory score was found for colour, odour and texture and appearance for shrimp L. vannamei collected from Ranpar farm was $4.8 \pm 0.45,4.4 \pm 0.55,4.6 \pm 0.55$ and $5.0 \pm 0.00$ on first sampling respectively. Similarly for the second sampling the values obtained for the same attributes were $4.6 \pm 0.55,4.8 \pm 0.45,4.8 \pm 0.45$ and $4.8 \pm 0.45$. On the third sampling the values were found to be $4.8 \pm 0.45,4.6 \pm 0.55,4.8 \pm 0.45$ and $4.4 \pm 0.55$. The values found for colour, odour and texture and appearance for shrimp $L$. vannamei collected from Nevre farm was $5.0 \pm 0.00,4.6 \pm 0.55,5.0 \pm 0.00$ and $4.8 \pm 0.45$ on first sampling, respectively. Similarly during the second sampling the values obtained for the same attributes were $4.8 \pm 0.45,4.8 \pm 0.45$, $5.0 \pm 0.00$ and $4.6 \pm 0.55$. On the third sampling the values were found to be $4.4 \pm 0.55$, $4.8 \pm 0.45,4.8 \pm 0.45$ and $5.0 \pm 0.00$. The values found for colour, odour and texture and appearance for shrimp L. vannamei collected from Varavade farm was $4.8 \pm 0.45,5.0 \pm 0.00$, $4.8 \pm 0.45$ and $5.0 \pm 0.00$ on first sampling, respectively. Similarly during the second sampling the values obtained for the same attributes were $4.6 \pm 0.55,4.8 \pm 0.45,4.6 \pm 0.45$ and $4.8 \pm 0.45$. On the third sampling the values were found to be $5.0 \pm 0.00,4.8 \pm 0.45$, $4.8 \pm 0.45$ and $5.0 \pm 0.00$ (Table 2).

On similar line Puga-lopez et al., (2013) has reported the sensory analysis of farmed and wild harvested white shrimp Litopenaeus vannamei. The maximum values were found to be $4.75 \pm 0.18$ (Nayarit farm shrimp), $5.0 \pm 0.18$ (Nayarit farm shrimp) and $4.85 \pm 0.15$ (Sinaloa wild shrimp and Nayarit farm shrimp) for colour, odour and texture respectively for shrimp L. vannamei. The minimum values for same parameters were obtained to be $4.07 \pm 0.25$ (Sinaloa farm shrimp), 4.6 \pm 0.22 (Nayarit wild shrimp) and $5.04 \pm 0.15$ (Sinaloa farm shrimp) respectively. 
On the basis of present investigation of sensory score is correlated to above study. Don et al., (2018) assessed the changes in sensory parameters of L. vannamei cultured in Raigad district, Maharashtra, India. The changes in sensory characteristics were examined on 1-10 hedonic scale suggested by Vijayan (1984). As the shrimp samples were very fresh, it obtained an average score of 9.5 In relation to colour (Smith, 1930) observed an expansion of the chromatophore pigment with heat and a contraction with cold. Differences in proximate composition might result in differences in nutritional value, sensory qualities and shelf-life of the shrimps.

\section{Biochemical characteristics}

\section{Estimation of TMA-N and TVB-N}

The TMA-N content of shrimp samples were recorded before microbiological analysis. The highest TMA-N level was recorded in the samples collected from Varavade farm i.e. $3.3 \mathrm{mg} / 100 \mathrm{~g}$ and minimum was observed from Nevre farm i.e. $2.4 \mathrm{mg} / 100 \mathrm{~g}$ (Table 3). Significant differences $(\mathrm{p}<0.05)$ were found between three farms. Okpala et al., (2014) assessed the quality and shelf life of freshly harvested Pacific white shrimp (L. vannamei) harvested fresh from three different farms) located in Selangor, Peninsular Malaysia. TMA-N values of freshly harvested shrimps were $0.33 \pm 0.12 \mathrm{mg} \mathrm{N} / 100 \mathrm{~g}$. Don et al., (2018) assessed the shelf life prediction of farmed shrimp (L. vannamei).

The freshly caught samples were collected from a shrimp farm, Raigad district, Maharashtra, India. The TMA-N level of the sample was. $1.22 \mathrm{mg} / 100 \mathrm{~g}$. In the present study TMA-N value was obtained to be higher than that observed by Okpala et al., (2014) in L. vannamei harvested fresh from three different farms located in Selangor, Peninsular Malaysia.
The TMA content varies with species, origin, depth of living, season etc. TMAO, an organic osmolyte has a major role in stabilizing proteins, which are affected by harsh environments like higher salinity and high urea contents (Liao et al., 2017). Since the major content of TMA is from the reduction of TMAO, freshwater or brackish water samples have a lesser amount of TMA. Since TMAO, being an osmolyte, it helps in stabilising the proteins, which would have got destabilized by the increase in pressure in deeper waters. So, its content will be higher in deep water species. Changes in the nitrogenous compounds in shrimps occur as a result of both endogenous enzymatic and bacterial activity (Cobb and Vanderzant, 1971).

The determination of TVB-N is an indicator of freshness commonly used in the trade (Storey et al., 1984). It determination quantifies the nitrogenous bases (trimethylamine, dimethylamine and ammonia) produced during spoilage of shrimp (Galleguillos, 1996). The highest TVB-N level was found in the samples collected from Varavade farm i.e. $13.6 \mathrm{mg} / 100 \mathrm{~g}$ and the lowest was recorded in the samples collected from Ranpar farm i.e. $11.1 \mathrm{mg} / 100 \mathrm{~g}$. No significant differences were $(p>0.05)$ found between three farms. The detailed results are given in Table 4. The TVB-N values obtained from all three sites in Ratnagiri were very low as compared to results obtained by Okpala et al., (2014) and Puga-lopez et al., (2013). Okpala et al., (2014) assessed the quality and shelf life of freshly harvested Pacific white shrimp (L. vannamei) harvested fresh from three different farms) located in Selangor, Peninsular Malaysia. TVB-N values of freshly harvested shrimps were $9.94 \pm 0.86$ mg N/100 g. Puga-lopez et al., (2013) was studied the biochemical analysis of farmed and wild harvested White shrimp L. vannamei tissues. 
Table.1 Proximate composition (\%) of samples collected from different farms of Ratnagiri i.e. Ranpar, Nevare and Varvade farm

\begin{tabular}{|l|l|l|l|l|l|}
\hline \multicolumn{7}{|c|}{ Ranpar Farm } \\
\hline Sampling & Protein & Fat & Moisture & Ash & Carbohydrate \\
\hline Sample I & $17.4 \pm 0.68$ & $1.3 \pm 0.04$ & $73.9 \pm 1.68$ & $1.5 \pm 0.23$ & $1.8 \pm 0.10$ \\
\hline Sample II & $17.0 \pm 1.14$ & $1.3 \pm 0.13$ & $77.6 \pm 1.26$ & $1.9 \pm 0.25$ & $2.1 \pm 0.10$ \\
\hline Sample III & $16.8 \pm 1.23$ & $1.5 \pm 0.10$ & $77.9 \pm 2.72$ & $1.4 \pm 0.33$ & $2.2 \pm 0.06$ \\
\hline \multicolumn{5}{|c|}{ Nevare Farm } \\
\hline Sample I & $16.8 \pm 1.44$ & $1.5 \pm 0.14$ & $75.6 \pm 1.00$ & $1.8 \pm 0.14$ & $1.5 \pm 0.10$ \\
\hline Sample II & $16.9 \pm 0.45$ & $1.5 \pm 0.09$ & $73.9 \pm 0.22$ & $1.6 \pm 0.30$ & $1.5 \pm 0.05$ \\
\hline Sample III & $17.6 \pm 1.12$ & $1.5 \pm 0.44$ & $75.6 \pm 1.67$ & $1.8 \pm 0.12$ & $1.7 \pm 0.11$ \\
\hline \multicolumn{5}{|c|}{ Varvade Farm } \\
\hline Sample I & $17.5 \pm 0.36$ & $1.5 \pm 0.12$ & $74.0 \pm 1.28$ & $1.8 \pm 0.05$ & $2.1 \pm 0.21$ \\
\hline Sample II & $17.2 \pm 0.60$ & $1.3 \pm 0.15$ & $73.2 \pm 0.51$ & $1.7 \pm 0.09$ & $2.2 \pm 0.18$ \\
\hline Sample III & $17.6 \pm 0.46$ & $1.5 \pm 0.14$ & $75.2 \pm 0.72$ & $1.9 \pm 0.10$ & $2.4 \pm 0.10$ \\
\hline
\end{tabular}

Table.2 Sensory attributes of samples collected from different farms of Ratnagiri i.e. Ranpar, Nevare, Varvade farm

\begin{tabular}{|l|l|l|l|l|}
\hline \multicolumn{5}{|c|}{ Ranpar Farm } \\
\hline Sample I & $4.8 \pm 0.45$ & $4.4 \pm 0.55$ & $4.6 \pm 0.55$ & $5.0 \pm 0.00$ \\
\hline Sample II & $4.6 \pm 0.55$ & $4.8 \pm 0.45$ & $4.8 \pm 0.45$ & $4.8 \pm 0.45$ \\
\hline Sample III & $4.8 \pm 0.45$ & $4.6 \pm 0.55$ & $4.8 \pm 0.45$ & $4.4 \pm 0.55$ \\
\hline \multicolumn{5}{|c|}{ Nevare Farm } \\
\hline Sample I & $5.0 \pm 0.00$ & $4.6 \pm 0.55$ & $5.0 \pm 0.00$ & $4.8 \pm 0.45$ \\
\hline Sample II & $4.8 \pm 0.45$ & $4.8 \pm 0.45$ & $5.0 \pm 0.00$ & $4.6 \pm 0.55$ \\
\hline Sample III & $4.4 \pm 0.55$ & $4.8 \pm 0.45$ & $4.8 \pm 0.45$ & $5.0 \pm 0.00$ \\
\hline \multicolumn{5}{|c|}{ Varvade Farm } \\
\hline Sample I & $4.8 \pm 0.45$ & $5.0 \pm 0.00$ & $4.8 \pm 0.45$ & $5.0 \pm 0.00$ \\
\hline Sample II & $4.6 \pm 0.55$ & $4.8 \pm 0.45$ & $4.6 \pm 0.45$ & $4.8 \pm 0.45$ \\
\hline Sample III & $5.0 \pm 0.00$ & $4.8 \pm 0.45$ & $4.8 \pm 0.45$ & $5.0 \pm 0.00$ \\
\hline
\end{tabular}

Table.3 Biochemical parameters of shrimp samples collected from different farms i.e. Ranpar, Nevare and Varvade farm

\begin{tabular}{|c|l|l|l|l|}
\hline Farm & Sample & $\begin{array}{l}\text { TMA-N } \\
(\mathbf{m g} / \mathbf{1 0 0 g})\end{array}$ & $\begin{array}{l}\text { TVB-N } \\
(\mathbf{m g} / \mathbf{1 0 0 g})\end{array}$ & $\begin{array}{l}\text { PV } \\
(\mathbf{m E q} \text { of O }\end{array}$ \\
& Sample I & $2.2 \pm 0.36$ & $12.9 \pm 0.68$ & $4.3 \pm 0.58$ \\
\hline \multirow{3}{*}{ Ranpar } & Sample II & $2.4 \pm 0.15$ & $13.6 \pm 0.37$ & $3.7 \pm 1.53$ \\
\cline { 2 - 5 } & Sample III & $2.4 \pm 0.15$ & $11.1 \pm 1.01$ & $3.7 \pm 0.58$ \\
\hline \multirow{3}{*}{ Nevre } & Sample I & $2.7 \pm 0.86$ & $13.0 \pm 0.93$ & $4.7 \pm 0.58$ \\
\cline { 2 - 5 } & Sample II & $3.0 \pm 0.60$ & $13.0 \pm 0.54$ & $3.3 \pm 5.58$ \\
\cline { 2 - 5 } & Sample III & $2.4 \pm 0.50$ & $13.0 \pm 0.43$ & $3.7 \pm 0.58$ \\
\hline \multirow{3}{*}{ Varavade } & Sample I & $3.3 \pm 0.26$ & $13.1 \pm 0.24$ & $2.3 \pm 0.58$ \\
\cline { 2 - 5 } & Sample II & $3.3 \pm 0.42$ & $13.4 \pm 0.74$ & $3.0 \pm 1.00$ \\
\cline { 2 - 5 } & Sample III & $3.2 \pm 0.35$ & $13.0 \pm 0.36$ & $3.3 \pm 1.15$ \\
\hline
\end{tabular}


Table.4 Microbiological characteristics of samples collected from different farms of Ratnagiri i.e. Ranpar, Nevare and Varvade

\begin{tabular}{|c|c|c|c|c|c|c|c|}
\hline \multirow{2}{*}{$\begin{array}{l}\text { Sr. } \\
\text { No }\end{array}$} & \multirow{2}{*}{$\begin{array}{l}\text { Farm } \\
\text { Sample } \\
\text { No }\end{array}$} & \multicolumn{6}{|c|}{ Ranpar } \\
\hline & & TPC & S. aureus & E. coli & Salmonella & $\begin{array}{c}\text { Pseudomonas } \\
\text { spp }\end{array}$ & L. monocytogenes \\
\hline 1 & I & $0.57 \times 10^{6}$ & $4.7 \times 10^{1}$ & ND & ND & ND & ND \\
\hline 2 & II & $0.73 \times 10^{6}$ & $6.7 \times 10^{1}$ & ND & ND & ND & ND \\
\hline 3 & III & $1.03 \times 10^{6}$ & $8.7 \times 10^{1}$ & ND & ND & ND & ND \\
\hline $\begin{array}{l}\text { Sr. } \\
\text { No }\end{array}$ & $\begin{array}{l}\text { Farm } \\
\text { Sample } \\
\text { No }\end{array}$ & \multicolumn{6}{|c|}{ Nevare } \\
\hline 1 & I & $0.53 \times 10^{6}$ & $6.7 \times 10^{1}$ & ND & ND & ND & ND \\
\hline 2 & II & $0.67 \times 10^{6}$ & $5.7 \times 10^{1}$ & ND & ND & ND & ND \\
\hline 3 & III & $0.9 \times 10^{6}$ & $11.3 \times 10^{1}$ & ND & ND & ND & ND \\
\hline $\begin{array}{l}\text { Sr. } \\
\text { No }\end{array}$ & $\begin{array}{l}\text { Farm } \\
\text { Sample } \\
\text { No }\end{array}$ & \multicolumn{6}{|c|}{ Varvade } \\
\hline 1 & I & $0.47 \times 10^{6}$ & $4 \times 10^{1}$ & ND & ND & ND & ND \\
\hline 2 & II & $0.63 \times 10^{6}$ & $6.3 \times 10^{1}$ & ND & ND & ND & ND \\
\hline 3 & III & $0.77 \times 10^{6}$ & $9.3 \times 10^{1}$ & ND & ND & ND & ND \\
\hline
\end{tabular}

The samples were collected from two different farms, whereas the wild shrimp were collected off the coasts of Sinola and Nayarit, Maxico. The TVBN values fluctuated between 35.35 \pm 1.64 (Sinola farm shrimp) maximum and $32.34 \pm 1.03$ (Nayarit farm shrimp) minimum. Don et al., (2018) worked on the shelf life prediction of farmed shrimp (L. vannamei). The freshly caught samples were collected from a shrimp farm, Raigad district, Maharashtra, India. The TVBN content of the sample was $8.01 \mathrm{mg} / 100 \mathrm{~g}$. The TVBN value greater than $25 \mathrm{mg} / 100 \mathrm{~g}$ was considered as reported by Okpala et al., (2014). Chang et al., (1983) refer that shrimp initially presenting $18 \mathrm{mg} / 100 \mathrm{~g}$ are of good but not of prime quality.

\section{Estimation of peroxide value}

The highest level of Peroxide value was observed in the samples collected from Nevre farm i.e. $4.7 \mathrm{mg} / 100 \mathrm{~g}$ and the lowest in samples of Varavade i.e. $2.3 \mathrm{mg} / 100 \mathrm{~g}$ (Table 3). No significant difference was observed between the farms in Ratnagiri. Okpala et al., (2014) worked on the quality and shelf life assessment of pacific white shrimp $L$. vannamei. The peroxide value of freshly harvested shrimp sample was recorded $1.56 \pm$ $0.27 \mathrm{mEq}$ of $\mathrm{O}_{2} / \mathrm{kg}$.

In the present investigation the value of PV of L. vannamei from all 3 farm sites fluctuated between 2.3 \pm 0.58 (Varavade farm) to $4.7 \pm 0.58$ (Nevre farm). In the earlier study on L. vannamei from Farms located in Selangor, Peninsular Malaysia by Okpala et al., (2014); $\mathrm{PV}$ value of $1.56 \pm 0.27 \mathrm{mEq}$ of $\mathrm{O}_{2} / \mathrm{kg}$ was observed which was very low as compared to present results.

\section{Microbiological analysis}

Several studies have indicated that the stressors in aquaculture are mostly related to 
water and pond sediment quality (Lo and Kou, 1998). Takashashi et al., (1995) reported that water quality parameters such as $\mathrm{pH}$, salinity, temperature and hardness make shrimp susceptible to pathogens. Significant difference in the soil and water quality parameters between disease affected and unaffected ponds have been also recorded (Krishnani et al., 1997). In shrimp aquaculture, high stocking densities coupled with use of large amount of feeds are being practiced to maximize productions. Many times due to poor pond management practices, critical water parameters might be beyond the optimal levels irrespective of stocking density.

Organic matter that originates from unused feed and fecal material settle at the pond bottom, followed by of microbial metabolism, resulting in high amounts of nutrients and metabolites (ammonia, nitrate, nitrite, sulfide) in high stocking shrimp ponds (Joseph et al., 2001). Generally these are recycled either by native microorganisms or by application of microbial products. Exposure to stressors originating from pond water could compromise the immunity of aquatic organisms, thereby increasing the risk of infection and physico-chemical condition of pond may stimulate the proliferation of pathogens (Tendencia et al., 2012).

The most important factor in shrimp culture is the maintenance of a good quality pond bottom. Once the pond bottom reaches a poor condition, from an increase in accumulation of organic sludge, shrimp will not grow at normal rates (Fast and Boyd 1992), as seen in this study in spite the addition of bioremediation products. The condition of the pond bottom quickly deteriorated with the progress of the culture period, because the pond bottom was not cleaned before stocking. In addition, the condition further deteriorated with the accumulation of organic sediment from feed and faecal matter it helps to growth of different microorganisms reported by Masters and Smith (1996). Since all the human pathogenic bacteria discussed below have been found to be indigenous to tropical shrimp culture environment, assays other than those which detect faecal coliforms or Escherichia coli must be used for assessing the public health risk in such tropical systems (Perez Rozan and Hazan 1989) and foods harvested from such systems.

\section{Enumeration of total plate count}

The total bacterial count of samples was collected from Ranpar, Nevre and Varavade varied between $0.57 \times 10^{6}$ to $1.03 \times 10^{6}$, $0.57 \times 10^{6}$ to $0.9 \times 10^{6}$ and $0.47 \times 10^{6}$ to $0.77 \times 10^{6}$ cfu/g respectively (Table 4 ). Samia et al., (2014) studied microbial quality analysis of shrimps collected from market around Dhaka city. The total aerobic bacterial load was found to be higher $\left(1.2 \times 10^{4} \mathrm{cfu} / \mathrm{g}\right.$ to $3.3 \times 10^{4}$ $\mathrm{cfu} / \mathrm{g})$ in all parts of shrimp samples.

Yusuf et al., (2008) worked on prevalence of microbial load in shrimp ( $P$. monodon). The total plate count was ranged between $2.04 \times 10^{2}$ to $4.5 \times 10^{5} \mathrm{CFU} / \mathrm{ml}$. Total plate count(TPC) of shrimp samples collected from different farms located nearby Ratnagiri was recorded low as compared with Samia et al., (2014) and Yusuf et al., (2008)

\section{Enumeration of Staphylococcus aureus}

The Staphylococcus count of samples was collected from Ranpar, Nevre and Varavade varied between $4.7 \times 10^{1}$ to $8.7 \times 10^{1}, 6.7 \times 10^{1}$ to $11.3 \times 10^{1}$ and $4 \times 10^{1}$ to $9.3 \times 10^{1}$ respectively (Table 4). Samia et al., (2014) worked on microbial contamination of shrimp samples collected from market around Dhaka city. The load of Staphaylococcus spp. was detected within a range of $2.7 \times 10^{5} \mathrm{cfu} / \mathrm{g}$ to $2.3 \times 10^{7}$ $\mathrm{cfu} / \mathrm{g}$. 
Enumeration of E. coli, Pseudomonas spp, L. monocytogenes and Salmonella spp.

E. coli was not detected in sample collected from all farms throughout the study (Table 4). Samia et al., (2014) assessed bacterial contamination from the samples collected from the markets around Dhaka city. E. coli was absent in all the samples. The sanitary conditions of white leg shrimp are best in all three farms located at Ratnagiri. Faecal coliform contents in shrimps vary depending on the sanitary and hygienic conditions of the landing centres or farm (Ali et al., 2012; Hossain et al., 2010). Most of studies revealed that the presence of faecal coliform is not permitted in the shrimp samples in Japan, USA and other European countries (Azzam et al., 2010).

Pseudomonas Spp was not detected in sample collected from all throughout the study while Samia et al., (2014) worked on microbial contamination of shrimp samples collected from market around Dhaka city the Pseudomonas spp. was found within the range $2.2 \times 10^{5} \mathrm{cfu} / \mathrm{g}$ to $7.9 \times 10^{7}$ in some samples and it was absent in remaining species.

It was noticed; in the present study $L$. monocytogenes was not detected in sample collected from all farms throughout the study. The routes of contamination might be unhygienic handling, contaminated water source, improper packaging, transportation and storage (Antony et al., 2002). International Commission of Microbiological Commission for Food (ICMCF) suggested that $L$. monocytogenes should not be detected in $25 \mathrm{~g}$ of raw shrimps (FAO, 1999).

Salmonella was not detected in sample collected from all farms i.e. Nevre, Varvade and Ranpar throughout the study (Table 4). From public health point of view, shrimp safety is becoming more of concern. The expanded international seafood trade has facilitated the introduction of pathogen into new geographic areas and human communities. Meanwhile the extensive use of antibiotics in intensive aquaculture has increased the development of multiple resistant pathogenic bacteria. This concern has been highlighted by an elevated prevalence antimicrobial resistant Salmonella in shrimp (Norhana, et al., 2001 and Zhao et al., 2003). International Commission of Microbiological Commission for Food (ICMCF) suggested that Salmonella should not be detected in $25 \mathrm{~g}$ of raw shrimps (FAO, 1999)

In conclusions, the results of our study suggested that muscles of farmed white leg shrimp are a good source of protein and lipid. The differences in physicochemical compositions, microbiological and sensorial properties between different farms located nearby Ratnagiri coast might be associated with the origin and handling. There were nonsignificant differences $(p<0.05)$ between different farmed shrimp. Shrimp collected from Varavade farm tend to have a better proximate composition than the other ones. This is due to the greater variety of foods available in their environment. According to sensory evaluation and biochemical results all three farmed shrimps are good for human consumption and all these parameters are within acceptable limit. Similarly microbiological parameters such as TPC and $S$. aureus are within acceptable limit while Pathogenic bacteria such as E. coli, $L$. monocytogenes and Salmonella were not detected all three farms during throughout the present study. These results indicate that aquaculture practices greatly influence the bacterial profile of the white leg shrimp, and further suggest that bacterial communities of this economically important crustacean could be effectively manipulated using diet composition or environmental conditions. 


\section{References}

Ali, S. S. R., Ramachandran, M., Chakma, S. K., and Asrar, M. (2017). Proximate composition of commercially important marine fishes and shrimps from the Chennai coast, India. Int. J. Fish. Aquat. Stud, 5(5), 113-119.

American Oil Chemistry Society (AOCS Method, 2011). Estimation of Peroxide Value

American Public Health Association, American Water Works Association, Water Pollution Control Federation, and Water Environment Federation. (1992). Standard methods for the examination of water and wastewater (Vol.2). American Public Health Association.

Antony, M. M., Jeyasekaran, G., Jeya Shakila, R., and Shanmugam, S. A. (2002). Biochemical quality of raw shrimps processed in seafood processing plants located in Tuticorin region of Tamil Nadu, India. Journal of food science and technology, 39(6), 698-701.

Association of Official Analytical Chemists. (AOAC Method, 2005). Official Methods of Analysis: Changes in Official Methods of Analysis Made at the Annual Meeting. Supplement (Vol. 15). Association of Official Analytical Chemists.

Azzam, M., Sekheta, F., Sahtout, A.H., Hisham, A., Sekheta, F., Sharabi, R.O., Airoud, K.A. (2010). The group of hidden hazards in enhanced HACCP and ISO-22000 based quality systems. International Journal of Food Safety 12, 146-157.

Beatty, S. A., and Gibbons, N. E. (1936). The measurement of spoilage in fish. Journal of the Biological Board of Canada, 3(1), 77-91.

Bhaskar, N., Setty, T. R., Reddy, G. V. S., Manoj, Y. B., Anantha, C. S.,
Raghunath, B. S., and Antony, J. M. (1995). Incidence of Salmonella in cultured shrimp Penaeus monodon. Aquaculture, 138(1-4), 257 266.

Chang, O., Cheuk, W. L., Nickelson, R., Martin, R., and Finne, G. (1983). Indole in shrimp: effect of fresh storage temperature, freezing and boiling. Journal of Food science, 48(3), 813-816.

Cobb III, B. F., and Vanderzant, C. (1971). Biochemical changes in shrimp inoculated with Pseudomonas, Bacillus and a Coryneform bacterium. Journal of Milk and Food Technology,34(11), 533-547.

Connor, W. E., Neuringer, M., and Reisbick, S. (1992). Essential fatty acids: the importance of $n-3$ fatty acids in the retina and brain. Nutrition reviews, 50(4), 21-29.

Dalgaard, P., and Jørgensen, L. V. (2000). Cooked and brined shrimps packed in a modified atmosphere have a shelf- life of> 7 months at $0^{\circ} \mathrm{C}$, but spoil in 4-6 days at $25^{\circ} \mathrm{C}$. International journal of food science and technology, 35(4), 431-442.

Dalsgaard, A., Huss, H. H., H-Kittikun, A., and Larsen, J. L. (1995). Prevalence of Vibrio cholera and Salmonella in a major shrimp production area in Thailand. International journal of food microbiology, 28(1), 101-113.

Davis, D. A., Lawrence, A. L., and Gatlin III, D. M. (1992). Mineral requirements of Penaeus vannamei: a preliminary examination of the dietary essentiality for thirteen minerals. Journal of the World Aquaculture Society, 23(1), 8-14.

Don, S., Xavier, K. M., Devi, S. T., Nayak, B. B., and Kannuchamy, N. (2018). Identification of potential spoilage bacteria in farmed shrimp (Litopenaeus vannamei): Application of Relative Rate 
of Spoilage models in shelf lifeprediction. $L W T, 97,295-301$.

FAO (1999). Report of the FAO expert consultations on the trade impact of Listeria in fish products. FAO Fisheries Report No. 604. Rome: Food and Agricultural Organization of the United Nations.

FAO, The State of World Fisheries and Aquaculture $2016 \quad$ (SOFIA): Contributing to food security and nutrition for all, Rome: Food and Agriculture Organization.

Fast A.W. and Boyd C.E. (1992) (ed. by A.W. Fast and J.L. Lester) Pond monitoring and management. In: Marine Shrimp Culture Principles and Practices, Elsevier Science Publishers, Amsterdam. pp. 497-513.

Galleguillos, M., (1996). Certification control Y quality fishmeal. In: Mendoza Alfaro, R.E., L.E. Cruz-Suarez and D. Ricque (Eds.), Proceeding of the Nutricion Acuicola. 2nd International Symposium, 367-372.

Gunalan, B., Soundarapandian, P., and Anand, T. (2013). Nutritive value of cultured white leg shrimp Litopenaeus vannamei. International journal of fisheries and Aquaculture,5(7), 166171.

Heu, M. S., Kim, J. S., and Shahidi, F. (2003). Components and nutritional quality of shrimp processing by-products. Food Chemistry, 82(2), 235-242.

Hossain, A., Mandal, S. C., Rahman, M. S., Rahman, M. M., and Hasan, M. (2010). Microbiological quality of processed frozen black tiger shrimps in fish processing plant. World Journal of Fish and Marine Sciences, 2(2), 124-128.

Huidobro, A., López-Caballero, M., and Mendes, R. (2002). Onboard processing of deepwater pink shrimp (Parapenaeus longirostris) with liquid ice: effect on quality. European Food Research and
Technology, 214(6), 469-475.

Iao, Y. T., Manson, A. C., DeLyser, M. R., Noid, W. G., and Cremer, P. S. (2017). Trimethylamine N-oxide stabilizes proteins via a distinct mechanism compared with betaine and glycine. Proceedings of the National Academy of Sciences, 114(10), 24792484.

Joseph G., Kharnaior E. and Kumari KR. R. (2017). Physicochemical and microbiological quality of aquaculture farms of Chellanam Panchayath, Ernakulam. International Journal of Fisheries and Aquatic Studies, 5(5), 428-437.

Joseph, K.O., Gupta, B.P., Muralidhar, M and Krishnani, K.K. (2001). (Eds. N. R. Menon, B. Madhusoodana Kurup and Rosamma Philip). Changing patterns in the soil and water conditions of the coastal regions due to intensification of shrimp farming. Aquaculture and Environment Centre for Integrated Management of Coastal Zones. Pp.157 169.

Karakoltsidis, P.A., A. Zotosand and S.M. Constantinides, (1995). Composition of the commercially important Mediterranean finfish, crustaceans and mollusks. J. Food Comp. Anal., 8: 258273.

Karunasagar, I., Vinod, M. G., Kennedy, B., Vijay, A., Deepanjali, A., Umesh, K., and Karunasagar, I. (2005). Biocontrol of bacterial pathogens in aquaculture with emphasis on phage therapy. In Diseases in Asian Aquaculture V, Fish Health Section, Asian Fisheries Society, Proceedings of the Fifth Symposium on Diseases in Asian Aquaculture (pp. 535-542).

Krishnani, K. K., Rajendran, K. V., Joseph, K. O., and Gupta, B. P. (1997). Soil and water characteristics of shrimp ponds affected with viral disease. J. Inland 
Fish. Soc. India, 29(1), 37-42.

Lo, C. F., and Kou, G. H. (1998). Virusassociated white spot syndrome of shrimp in Taiwan: a review. Fish pathology, 33(4), 365-371.

MacDonald P, Greenhalgh JFD, Morgan CA. (1998) Animal Nutrition, 5th edition: Longman Publication., 607.

Masters, S. J., and Smith, P. T. (1996). Origin of reduced sulfur compounds in pond sediment. In Proceedings Sustainable Aquaculture' 95, PaciŪc Congress on Marine Science and Technology (p. 255ą260).

Motes JR, M. L. (1991). Incidence of Listeria spp. in shrimp, oysters, and estuarine waters. Journal of food protection, 54(3), 170-173.

MPEDA, 2018. MPEDA annual report 2017. 2018.

Norhana, M. W., Johara, M. Y., and Ramlah, A. M. (2001). Occurrence of pathogens from major shrimp and oyster production areas in Peninsular Malaysia. Malaysian Fisheries Journal, 2(1), 176-184.

Okpala, C. O. R. (2015). The physicochemical changes of farm-raised Pacific white shrimp (Litopenaeus vannamei) as influenced by iced storage. Food and Nutrition Sciences, 6(10), 906.

Okpala, C. O. R., Choo, W. S., and Dykes, G. A. (2014). Quality and shelf life assessment of Pacific white shrimp (Litopenaeus vannamei) freshly harvested and stored on ice. LWT-Food Science and Technology, 55(1), 110116.

Okpala, O. R. (2014). Changes of physicochemical properties of sequential minimal ozone treated ice-stored pacific white shrimp (Litopenaeus vannamei). Current Nutrition and Food Science, 10(3), 218-227.

Oksuz, A., Ozyilmaz, A., Aktas, M., Gercek,
G., and Motte, J. (2009). A comparative study on proximate, mineral and fatty acid compositions of deep seawater rose shrimp (Parapenaeus longirostris, Lucas 1846) and red shrimp (Plesionika martia, A. Milne-Edwards, 1883). Journal of Animal and Veterinary Advances, 8(1), 183-189.

Pillay, K. K., and Nair, N. B. (1973). Observations on the biochemical changes in gonads and other organs of Uca annulipes, Portunus pelagicus and Metapenaeus affinis (Decapoda: Crustacea) during the reproductive cycle. Marine Biology, 18(3), 167-198.

Puga Lopez, D., Ponce Palafox, J. T., BarbaQuintero, G., Torres-Herrera, M.R., Romero-Beltrán, E., Arredondo Figueroa, J. L., and Garcia-Ulloa Gomez, M. (2013). Physicochemical, proximate composition, microbiological and sensory analysis of farmed and wild harvested white shrimp Litopenaeus vannamei (Bonne, 1931) tissues.

Rostini, I., and Pratama, R. I. (2018, July). Effect of steaming on physical and chemical characteristics White Shrimp (Litopenaeus vannamei) from Indramayu Waters. In IOP Conference Series: Earth and Environmental Science (Vol. 176, No. 1, p. 012046). IOP Publishing.

Samia, S., Galib, H. T., Tanvir, A. S., Basudeb, C. S., Walliullah, M., Tasnia, A., and Mrityunjoy, A. (2014). Microbiological quality analysis of shrimps collected from local market around Dhaka city. International Food Research Journal, 21(1), 33.

Smith, D. C. (1930). The effects of temperature changes upon the chromatophores of crustaceans. The Biological Bulletin, 58(2), 193-202.

Sriket, P., Benjakul, S., Visessanguan, W., and Kijroongrojana, K. (2007). Comparative studies on chemical 
composition and thermal properties of black tiger shrimp (Penaeus monodon) and white shrimp (Penaeus vannamei) meats. Food chemistry, 103(4), 11991207.

Storey, R. M., Davis, H. K., Owen, D., and Moore, L. (1984). Rapid approximate estimation of volatile amines in fish. International Journal of Food Science and Technology, 19(1),

Tendencia, E. A., Bosma, R. H., Primavera, J. H., and Verreth, J. A. (2012). Effect of different mangrove-to-pond area ratios on influent water quality and WSSV occurrence in Penaeus monodon semiintensive farms using the greenwater culture technique. Aquaculture, 362, 7279.

Vijayan, P. K. (1984). Report on training program on retort pouch processing of fish and fish analysis at tropical development and research institute and METAL Box (R and D), UK. Central Institute of Fisheries Technology, Cochin.
Wallace, B. J., Guzewich, J. J., Cambridge, M., Altekruse, S., and Morse, D. L. (1999). Seafood-associated disease outbreaks in New York, 19801994. American journal of preventive medicine, 17(1), 48-54.

Yousuf, A. H. M., Ahmed, M. K., Yeasmin, S., Ahsan, N., Rahman, M. M., and Islam, M. M. (2008). Prevalence of microbial load in shrimp, Penaeus monodon and prawn, Macrobrachium rosenbergii from Bangladesh. World Journal of Agricultural Sciences, 4(5), 852-855.

Zar, J. H. (2014). Biostatistical analysis: Pearson new international edition. Pearson Higher Ed.

Zhao, S., Datta, A. R., Ayers, S., Friedman, S., Walker, R. D., and White, D. G. (2003). Antimicrobial-resistant Salmonella serovars isolated from imported foods. International journal of food microbiology, 84(1), 87-92.

\section{How to cite this article:}

Tawade, P.S., J.M. Koli, S.B. Patange, S.T. Sharangdher and Mohite, A.S. 2019. Biochemical and Microbiological Quality of Cultured Shrimp Litopenaeus vannamei of Different Farms of Ratnagiri. Int.J.Curr.Microbiol.App.Sci. 8(06): 2110-2124. doi: https://doi.org/10.20546/ijcmas.2019.806.251 